Hegyi, Pál. “Szőcs, Géza. 2017. Liberty, Rats and Sandpaper [Szabadság, spiclik, dörzspapír]. Trans. Paul Sohar. Island Heights, NJ: Iniquity Press. 112 pp.; Böszörményi, Zoltán. 2018. The Conscience of Trees [A fák lelkiismerete]. Trans. Paul Sohar. Princeton, NJ: Ragged Sky Press. 127 pp.” Hungarian Cultural Studies. eJournal of the American Hungarian Educators Association, Volume 11 (2018) DOI: 10.5195/ahea.2018.336

\title{
Szőcs, Géza. 2017. Liberty, Rats and Sandpaper [Szabadság, spiclik, dörzspapir]. Trans. Paul Sohar. Island Heights, NJ: Iniquity Press. 112 pp.; Böszörményi, Zoltán. 2018. The Conscience of Trees [A fák lelkiismerete]. Trans. Paul Sohar. Princeton, NJ: Ragged Sky Press. 127 pp.
}

\section{Reviewed by Pál Hegyi ${ }^{*}$, Eötvös Loránd University}

In 2017 and 2018 two significant volumes of Hungarian poetry translations were published, thus paying off a long-due debt accumulated by decades of belatedness. Both volumes were translated by poet and literary translator Paul Sohar, whose undeniably difficult task spanned over years until the original poetry collections of Géza Söcs and Zoltán Böszörményi came into their English versions. To judge by the outcome, Sohar's dedication to the task of introducing two widely known representatives of contemporary Hungarian poetry to an international readership resulted in unwavering success.

Liberty, Rats and Sandpaper (2017) offers a selection of poems from the oeuvre of Géza Szőcs, a towering figure in Hungarian poetry. Poet, writer, politician and a holder of multiple Romanian, Hungarian, and international awards including the Graves Prize (1986) and the Prize of the European Academy of Vienna (2009), Szöcs has since 2011 been the elected President of the Hungarian Pen Club. His political conduct upholding the banner of freedom under the Romanian communist regime - a stance that in 1986 forced him into exile — is paralleled by a similarly revolutionary attitude in his avant-garde, postmodernist poetry. Szőcs's twofold dedication to politics and poetry is ostensibly mirrored in the structure of the present volume that offers English-speaking readers a selection of the poet's work published since the 1970s but never before in English. Part I introduces the reader new to Szőcs's compelling poetry to such masterpieces as "The Great Marinetti Car" ['A nagy Marinetti autó'] (13), "The Ship Propeller" ['A hajócsavar'] (17), "The Twenty-third Snowfall" ['A huszonharmadik hóhullás'] (22), "Evening Prayer" ['Esti ima'] (26), "Listening to Muhammad Ali" ['Muhammad Ali két verse'] (30), "For my Birthday" ['Születésnapomra'] (54), and "Kafka and his Sister Stop in Budapest on their Way to Lebanon and Run into the Artist Csontváry" ['Kafka és növére...'] (72). As the titles of these poems imply, the aim of this inevitably restricted selection is to showcase in their

*hegyi.pal@btk.elte.hu

$($ (c) $)$ EY

ULIS D-Sorke
New articles in this journal are licensed under a Creative Commons Attribution 4.0 International License.

This journal is published by the University Library System of the University of Pittsburgh as part of its D-Scribe Digital Publishing Program and is cosponsored by the University of Pittsburgh Press 
Hegyi, Pál. “Szőcs, Géza. 2017. Liberty, Rats and Sandpaper [Szabadság, spiclik, dörzspapír]. Trans. Paul Sohar. Island Heights, NJ: Iniquity Press. 112 pp.; Böszörményi, Zoltán. 2018. The Conscience of Trees [A fák lelkiismerete]. Trans. Paul Sohar. Princeton, NJ: Ragged Sky Press. 127 pp.” Hungarian Cultural Studies. eJournal of the American Hungarian Educators Association, Volume 11 (2018) DOI: 10.5195/ahea.2018.336

multitude the most characteristic qualities, tonalities and poetic innovations of the vast corpus created by this astoundingly prolific poet.

Szőcs (b. 1953 in Târgu Mureș, Romania) started his literary career in his twenties as the enfant terrible of Hungarian poetry. By the age of twenty-six he had already published three volumes of poetry that managed to upset all conventional poetic expectations. His ironic, even grotesque paraphrases of traditional norms and forms combined with a playful tone emerging from the most intricate and refined intertextual ploys are powerfully present in his poignant poetry. These daring forays into the uncharted territories of poetic creation are often conveyed by the figure of catachresis, the mark of the "unthought," as formulated by Enikő Bollobás with regard to Emily Dickinson's poetry (on which see: Bollobas, "Troping the Unthought: Catachresis in Emily Dickinson's Poetry," The Emily Dickinson Journal 21.1, Spring 2012, 2556). Meaning, the poet's work is saturated by a web of literary, historical, sociopolitical, and cultural connotations, a context informed by a polyglot, cosmopolitan, international orientation. This epistemological framework inadvertently paves the path toward Szöcs's particular poetics, which locates the source of all poetic innovation in the realm between what is existent and what is not, or between the possible and the impossible. While reading through the translations of Szöcs's mesmerizing poems, one soon realizes that the first part of this collection creates a very special vantage point for its reader. The synchronic juxtaposition of early poems by the young virtuoso with the same poet's later pieces discloses a secret. It soon turns out that the postmodern interplays between switching timelines and shifting perspectives in Szőcs's poetry are not bereft of the moral, ethical, and metaphysical dimensions of the human condition as he has experienced it in the flesh. These poems tear open the chasms of existence, yet their music does not stop playing before offering consolation to the sunken heart.

Whereas Part I of Szőcs's poetry volume presents some of the most highly canonized poems of his political writing, including "Ballad about the Police Search of Our Home" ['Dal $a$ házkutatásról'] (37) and "Indian Words on the Radio" ['Indián szavak a rádióban'] (71), Part II is exclusively centered around verse excerpts from the author's imposing play entitled Liberté '56. This piece, written in 2005 and produced in Hungary a year later for the fiftieth anniversary of the Revolution, is an absorbing compound genre made up of drama, poetry, and movie script. Political activism as part of the artist's endeavors has a strong and long-standing tradition in Hungarian culture, and Géza Szőcs, like so many of his predecessors treading this path of creation before him, decided to take an active role in shaping the political events affecting the lives of his ethnic fellow-countrymen whether under Soviet communism or the Romanian rule of Transylvania. A protest letter he wrote in 1989 about the suffering of women under Romanian dictatorship, wherein they were regularly and non-hygienically examined by state-appointed gynecologists to see if they had undergone illicit abortions, is included in the addenda concluding the volume. This shocking text, which was originally addressed to American thinker Gloria Steinem, testifies to the poet's determination and perseverance.

Just as the poet's polyglot cultural background informs the postmodernist oeuvre of Géza Szőcs, a similarly multilingual and cosmopolitan mindset or spirit characterizes the modernist poetry of Zoltán Böszörményi (b. 1951 in Arad, Romania). Having published his first two volumes of poetry in communist Romania in his twenties, Böszörményi suffered constant 
Hegyi, Pál. “Szőcs, Géza. 2017. Liberty, Rats and Sandpaper [Szabadság, spiclik, dörzspapír]. Trans. Paul Sohar. Island Heights, NJ: Iniquity Press. 112 pp.; Böszörményi, Zoltán. 2018. The Conscience of Trees [A fák lelkiismerete]. Trans. Paul Sohar. Princeton, NJ: Ragged Sky Press. 127 pp.” Hungarian Cultural Studies. eJournal of the American Hungarian Educators Association, Volume 11 (2018) DOI: 10.5195/ahea.2018.336

harassment by the Secret Service, and was finally forced to migrate to Canada. The HegelianHeideggerian ontological dimensions of his poetry draw upon both his traumatic experience of exile and his unique sensibility emerging from an interconnectedness of diverse cultures, localities, and historical periods. The journey that The Conscience of Trees invites the reader to set on guides the perceiving mind to linger on objects of meditation. These intermittent objects record the transient footprints of the persona's wandering through space and time that are both infinite and intimate. A sense of the private sublime hovers above the initial lines of the second section of the book, entitled "The Dust of My Existence" ['Létem pora']: "My poem is a passing footprint / in the soft sands of your soul" ['Lelked homokjában versem, / Csak egy törölhetö lábnyom '] (39). Grounded in its particular sensitivity, Böszörményi's poetry creates an imaginary locale for innate communion between reader and poem. By delving into the everdecreasing core hiding within the confined space of a solitary consciousness, the persona's progress toward metaphysical transcendence is finally made possible. Suspending time, Böszörményi's poems record the fleeting moment. Time past comes alive in these poems so that the present is stopped short, if only for a second, before it vanishes into the past.

Böszörményi's poetry conspicuously features high modernist traits. The tension he creates by an alteration between classic meter and vers libre, his elaborate metaphors, abundant associations from antiquity to the contemporary with a special focus on mundane experience, his compelling mastery of versification and unquenchable desire for unity and redemption are all indicative of this poet's modernist sensibility. Yet, it is his uncompromising will to accept and incorporate the inherently fragile and vulnerable nature of any effort to grasp the meaning of our existence that makes Böszörményi a twenty-first century poet. His more recent poems, such as "The Ellipsis of Mercy" ['Az irgalom ellipszise'] (16), "Nikola Tesla's White Dove" ['Nikola Tesla fehér galambja'] (17), "Seaside Morning with Heidegger" ['Tengerparti reggel Heideggerrel'] (42), "Francesco Petrarca" ['Francesco Petrarca'] (83), "What Phaidros Forgot to Ask Socrates" ['Amit Phaidrosz nem kérdezett meg Szokratésztöl'] (29), and "The Mirage of our Fate" ['Sorsunk délibábja'] (81), all create a time and space of their own, wherein the general collides with the particular, the objective merges with the subjective, past becomes present, and experience unifies with the one experiencing it. Indeed, could there ultimately be a function more essential, yet more transparent for any poetry than Heideggerian Dasein?

This review set out by highlighting the quality of two volumes of poetry translations by Paul Sohar, thanks to which an international readership now has access to the works of two leading Hungarian poets. The question regarding the translatability of the poems by Géza Szőcs and Zoltán Böszörményi has to be addressed here for the very reason that it presents itself as a connecting link between the oeuvres of the two poets. Probably, Sohar's motivation for the enormous effort of translating the poems selected by the two poets is these poems' unique "Austro-Modernism," a term coined by Marjorie Perloff in her Edge of Irony - Modernism in the Shadow of the Habsburg Empire (Chicago: University of Chicago Press, 2016) to describe a recurring inflection in post-World War I East-Central European literary-poetic traditions. In the two poetry volumes at hand this inflection is expressed by a skeptical, disillusioned, ironic undertone and by a tendency to pose questions rather than offer answers. Perloff claims that this inflection is a direct consequence of the traumatic collapse of the multicultural and multilingual 
Hegyi, Pál. “Szőcs, Géza. 2017. Liberty, Rats and Sandpaper [Szabadság, spiclik, dörzspapír]. Trans. Paul Sohar. Island Heights, NJ: Iniquity Press. 112 pp.; Böszörményi, Zoltán. 2018. The Conscience of Trees [A fák

lelkiismerete]. Trans. Paul Sohar. Princeton, NJ: Ragged Sky Press. 127 pp." Hungarian Cultural Studies. eJournal of the American Hungarian Educators Association, Volume 11 (2018) DOI: 10.5195/ahea.2018.336

yet unified Austro-Hungarian Empire. Following the demise of the Empire, fragmented remnants of past uniform identities were dispersed into the polyglot multiethnic identities of the successor states and the annexed territories alike. Perloff further contends that the historical and political disruption caused by World War I created a new cultural condition in East-Central Europe, which she describes as cosmopolitan, traumatic and as a state of prolonged displacement. Perloff then expounds on the features of the post-Habsburg poetic creation and sees it as marked by loss and exile.

With time, these particularly East-Central European experiences of loss and exile became part of a multifaceted cultural heritage. The forms of expression that the Génération perdue had at its disposal have presently become parallel with a language that is always already translated, removed from its origin. This "Austro-Modernist" inflection, this unique modernist sensibility has found its way into the works of the two Hungarian poets reviewed here, too. Luckily for us, such a unique cultural and linguistic situation not only makes it possible for poet and master Hungarian-English translator Paul Sohar to excel in the mission of their poetic translation, but it also enables the English-speaking readership to get into intimate closeness with infinitude in the elegiac poems of dislocation written by Géza Szőcs and Zoltán Böszörményi. 